\title{
Bridging function mediated intermetallic coupling in diruthenium-bis(bipyridine) complexes
}

\author{
SOMA CHAKRABORTY, BIPLAB MONDAL, BIPRAJIT SARKAR and \\ GOUTAM KUMAR LAHIRI* \\ Department of Chemistry, Indian Institute of Technology - Bombay, Powai, \\ Mumbai 400 076, India \\ e-mail: lahiri@ether.chem.iitb.ac.in
}

\begin{abstract}
The interactions of potentially dinucleating bridging functionalities ( $\mathbf{F}$ VI) with the ruthenium-bis(bypyridine) precursor $\left[\mathrm{Ru}^{\mathrm{II}}(\mathrm{bpy})_{2}(\mathrm{EtOH})_{2}\right]^{2+}$ have been explored. The bridging functions I, II and VI directly result in the expected dinuclear complexes of the type $\left[(\text { bpy })_{2} \mathrm{Ru}^{\mathrm{II}}\left\{\mathrm{L}^{n}\right\} \mathrm{Ru}^{\mathrm{II}}(\mathrm{bpy})_{2}\right]^{z+}(\mathbf{1}, \mathbf{2}, \mathbf{7}$ and $\mathbf{8})(n=0, z=4$ and $n=-2, z=2$ ). The bridging ligand III undergoes $\mathrm{N}-\mathrm{N}$ or $\mathrm{N}-\mathrm{C}$ bond cleavage reaction on coordination to the $\mathrm{Ru}$ ( $\mathrm{bpy})_{2}$ core which eventually yields a mononuclear complex of the type $\left[(\text { bpy })_{2} \mathrm{Ru}^{\mathrm{II}}(\mathrm{L})\right]^{+}, \mathbf{3}$, where $\mathrm{L}={ }^{-} \mathrm{OC}_{6} \mathrm{H}_{3}(\mathrm{R}) \mathrm{C}\left(\mathrm{R}^{\prime}\right)=\mathrm{N}-\mathrm{H}$. However, the electrogenerated mononuclear ruthenium(III) congener, $\mathbf{3}^{+}$in acetonitrile dimerises to $\left[(\text { bpy })_{2} \mathrm{Ru}^{\mathrm{III}}\left\{{ }^{-} \mathrm{OC}_{6} \mathrm{H}_{3}(\mathrm{R}) \mathrm{C}\left(\mathrm{R}^{\prime}\right)=\mathrm{N}-\mathrm{N}=\left(\mathrm{R}^{\prime}\right) \mathrm{C}(\mathrm{R}) \mathrm{C}_{6} \mathrm{H}_{3} \mathrm{O}^{-}\right\} \mathrm{Ru}^{\mathrm{III}}(\mathrm{bpy})_{2}\right]^{4+}$ (4). In the presence of a slight amount of water content in the acetonitrile solvent the dimeric species (4) reduces back to the starting ruthenium(II) monomer (3). The preformed bridging ligand IV undergoes multiple transformations on coordination to the $\mathrm{Ru}(\mathrm{bpy})_{2}$ core, such as hydrolysis of the imine groups of IV followed by intermolecular head-to-tail oxidative coupling of the resultant amino phenol moieties, which in turn results in a new class of dimeric complex of the type $\left[(\mathrm{bpy})_{2} \mathrm{Ru}^{\mathrm{II}}\right.$ $\left.\left\{{ }^{-} \mathrm{OC}_{6} \mathrm{H}_{4}-\mathrm{N}=\mathrm{C}_{6} \mathrm{H}_{3}(=\mathrm{NH}) \mathrm{O}^{-}\right\} \mathrm{Ru}^{\mathrm{II}}(\mathrm{bpy})_{2}\right]^{2+}(\mathbf{5})$. In $\mathbf{5}$, the bridging ligand comprises of two $N, O$ chelating binding sites each formally in the semiquinone level and there is a $p$-benzoquinonediimine bridge between the metal centres. In complex $\mathbf{6}$, the preformed bridging ligand, 3,6-bis(3,5-dimethylpyrazol-1-yl)-1,2-dihydro-1,2,4,5tetrazine, $\mathrm{H}_{2} \mathrm{~L}(\mathbf{V})$ undergoes oxidative dehydrogenation to aromatic tetrazine based bridging unit, 3,6-bis(3,5-dimethylpyrazol-1-yl)-1,2,4,5-tetrazine, L. The detailed spectroelectrochemical aspects of the complexes have been studied in order to understand the role of the bridging units towards the intermetallic electronic coupling in the dinuclear complexes.
\end{abstract}

Keywords. Diruthenium complexes; metal-mediated transformations; intermetallic coupling; redox; spectroelectrochemistry.

\section{Introduction}

The development of newer classes of polynuclear ruthenium-polypyridine complexes incorporating suitable bridging functionalities are of considerable current research interest. This is primarily due to their potential use in diverse areas such as photosensitisers for photochemical conversion of solar energy ${ }^{1}$, molecular electronic devices ${ }^{2}$ and as photoactive DNA cleavage agents for therapeutic purposes ${ }^{3}$. The degree of electronic communication between the metal centres is essentially controlled by the electronic nature of the bridging units, which can mediate the electronic coupling through

\footnotetext{
*For correspondence
} 
their $\pi$-symmetry orbitals by either electron-transfer or hole-transfer mechanisms ${ }^{4}$. Bridging function mediated intermetallic electronic coupling is known to control the ground and excited state properties of such complexes.

In this context we have designed a group of new classes of diruthenium-bis(bipyridine) complexes incorporating neutral as well as anionic bridging functionalities and examined their spectroelectrochemical properties. Some of our recent observations are summarised in this note.

\section{Results and discussion}

The following neutral and anionic bridging ligands, I-VI (scheme 1) have been selectively chosen to synthesize diruthenium-bis(bipyridine) complexes of the type $\left[(\text { bpy })_{2} \mathrm{Ru}^{\mathrm{II}}\left\{\mathrm{L}^{n}\right\} \mathrm{Ru}^{\mathrm{II}}(\mathrm{bpy})_{2}\right]^{z+}(n=0, z=4$ and $n=-2, z=2)$. The bridging ligands (I-VI) essentially differ with respect to the electronic nature and charge associated with the donor centres.

The reactions of symmetric and neutral bridging ligands I and II with the rutheniumbipyridine starting complex, $\left[\mathrm{Ru}^{\mathrm{II}}(\mathrm{bpy})_{2}(\mathrm{EtOH})_{2}\right]^{2+}$ in dry ethanol under dinitrogen atmosphere result in diruthenium complexes of the types $\mathbf{1}$ and $\mathbf{2}$.

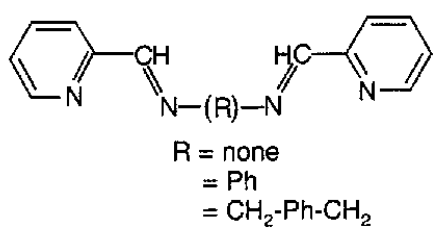

I

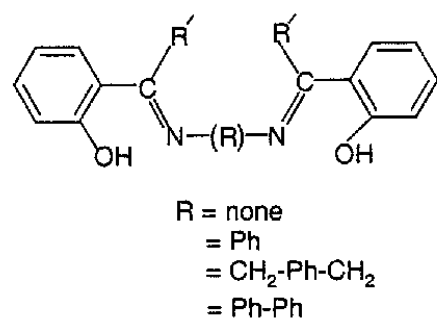

III<smiles>Cc1cc(C)n(C2=NNC(C3=NNC(C)C3)N=N2)n1</smiles>

Scheme 1.

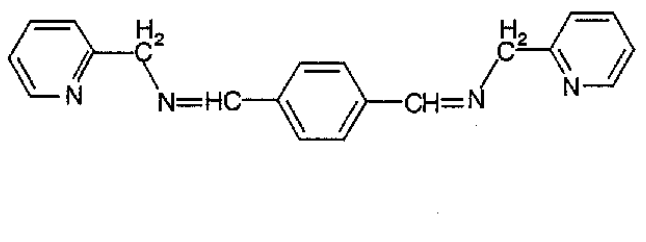

II

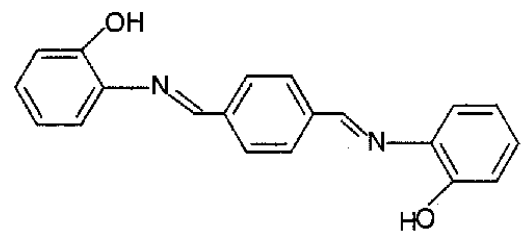

IV<smiles>Cc1cc(O)nc(S)n1</smiles>

VI 


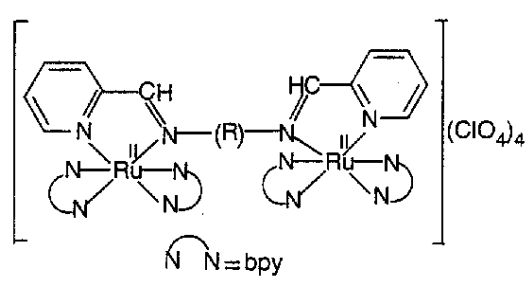

1

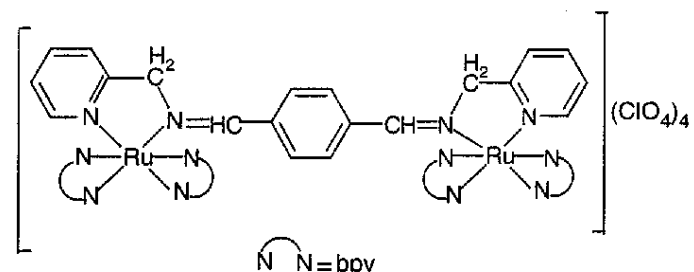

2

In acetonitrile solution the complex 1 exhibits one two-electron oxidation process near $1.5 \mathrm{~V}$ vs SCE corresponding to the simultaneous oxidations of the two ruthenium(II) centres in $\mathbf{1}^{5}$. The appearance of simultaneous oxidations of both the metal centres across the bridging unit (I) implies a situation of typical class I type dinuclear species where there is existence of no or very weak intermetallic coupling 2,5 .

In case of complex 2 , the two ruthenium(II) centres are found to undergo stepwise oneelectron reversible $\mathrm{Ru}(\mathrm{II}) / \mathrm{Ru}(\mathrm{III})$ oxidations at $1 \cdot 10 \mathrm{~V}$ and $1.35 \mathrm{~V}$ vs SCE in acetonitrile. Here the two $\mathrm{Ru}(\mathrm{II}) / \mathrm{Ru}(\mathrm{III})$ couples are separated by $225 \mathrm{mV}(\Delta E)^{6}$, which leads to the comproportionation constant $\left(K_{c}\right)$ for the equilibrium process $\mathrm{Ru}^{\mathrm{II}} \mathrm{Ru}^{\mathrm{II}}+\mathrm{Ru}^{\mathrm{III}} \mathrm{Ru}{ }^{\mathrm{III}} \square$ $2 \mathrm{Ru}^{\mathrm{II}} \mathrm{Ru}^{\mathrm{III}}, 1.7 \times 10^{4}\left[K_{c}\right.$ is obtained from the relation $R T \ln K_{c}=n F(\Delta E)$ where $\Delta E$ is the separation between the two $\mathrm{Ru}^{\mathrm{II}} / \mathrm{Ru}^{\mathrm{III}}$ couples ${ }^{7}$ ]. The observed $K_{c}$ value of $1.7 \times 10^{4}$ suggests that in $\mathbf{2}^{+}$the metal centres are electronically moderately coupled through the bridging unit II, as is expected from a class II system. Consequently, the electrochemically generated mixed-valence $\mathrm{Ru}^{\mathrm{II}} \mathrm{Ru}^{\mathrm{III}}$ species $\left(\mathbf{2}^{+}\right)$(258K, dichloromethane) displays a rhombic EPR spectrum at $77 \mathrm{~K}\left(g_{1}=2 \cdot 025, g_{2}=2.011 \text { and } g_{3}=1.906\right)^{6}$, which reflects the valence-trapped $\mathrm{Ru}^{\mathrm{II}} \mathrm{Ru} \mathrm{u}^{\mathrm{III}}$ configuration of the mixed-valence state $\left(2^{+}\right)$.

The reactions of diimine based dianionic bridging functions (III) with $\left[\mathrm{Ru}^{\mathrm{II}}(\mathrm{bpy})_{2}(\mathrm{EtOH})_{2}\right]^{2+}$ in presence of $\mathrm{CH}_{3} \mathrm{COONa}$ result in monomeric complexes of the type $3^{8}$. During the course of the reaction the $\mathrm{N}-\mathrm{N}$ or $\mathrm{N}-\mathrm{C}$ bond of the dinucleating bridging ligand (III) has been selectively cleaved, which eventually results in coordinated stable imine function incorporating the unusual $-\mathrm{C}(\mathrm{R})=\mathrm{N}-\mathrm{H}$ fragment. The formation of 3 has been authenticated by the crystal structures of two derivatives $\left(R^{\prime}=H\right.$ and $\left.M e\right)$. Although $\mathbf{3}$ is stable enough both in the solid and solution states, electrochemically generated ruthenium(III) congener $\left(3^{+}\right)$in dry acetonitrile slowly dimerises to the dimeric $\mathrm{Ru}^{\mathrm{III}} \mathrm{Ru}{ }^{\mathrm{III}}$ species, 4. However, in presence of a slight amount of water content in the acetonitrile the dimeric species (4) as well as $\mathbf{3}^{+}$reduce back to the initial monomeric ruthenium(II) complex 3 . The second order rate constant $(k)$ of the conversion process

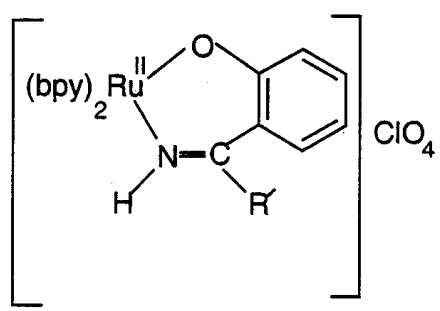

3

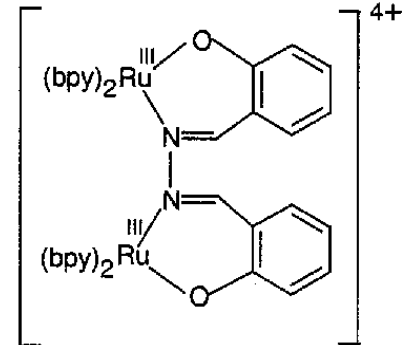

4 
$\mathbf{3}^{+} \rightarrow \mathbf{4}$ in dry acetonitrile and the first-order rate constant $\left(k^{\prime}\right)$ of $\mathbf{4} \rightarrow \mathbf{3}$ in ordinary acetonitrile and the activation parameters $\left(\Delta H^{\neq}\right.$and $\left.\Delta S^{\ddagger}\right)$ of both the processes have been determined in the temperature range $303-333 \mathrm{~K}$.

The dinucleating dianionic bridging ligand IV yields a new class of dirutheniumbis(bipyridine) complex 5. In 5, the hydrolysis of the imine groups of IV followed by intermolecular head-to-tail oxidative coupling of the resultant aminophenol fragments lead to the formation of a new N-C bond ${ }^{9}$. The crystal structures of $\mathbf{I V}$ and the complex, 5 have been determined. The structural parameters in combination with the spectroelectrochemical results indicate that in $\mathbf{5}$ the two nonequivalent $o$-iminophenol moieties are in semiquinone oxidation state and there is a $p$-benzoquinonediimine bridge between the two ruthenium centres.

It may be noted that under identical reaction conditions but in absence of IV the free $o$ amino phenol ligand fails to afford the complex $\mathbf{5}$, which indicates the strong possibility of initial coordination of $\mathbf{I V}$ to the $\mathrm{Ru}(\mathrm{bpy})_{2}$ cores prior to the transformation processes.

The bridging ligand in $\left[(\mathrm{bpy}){ }_{2} \mathrm{Ru}^{\mathrm{II}}\left\{\mathrm{L}^{\mathrm{sq}, \mathrm{sq}}\right\} \mathrm{Ru}^{\mathrm{II}}(\mathrm{bpy})_{2}\right]^{2+}(\mathbf{5})(\mathrm{sq}=$ semiquinone oxidation state) undergoes two successive reversible one-electron oxidations in acetonitrile $(0 \cdot 12$ and $0.35 \mathrm{~V}$ vs SCE) to $\left[(\mathrm{bpy})_{2} \mathrm{Ru}^{\mathrm{II}}\left\{\mathrm{L}^{\mathrm{q}, \mathrm{q}}\right\} \mathrm{Ru}^{\mathrm{II}}(\mathrm{bpy})_{2}\right]^{4+}\left(\mathbf{5}^{2+}\right)(\mathrm{q}=$ quinone oxidation state $)$. The electrogenerated one-electron paramagnetic intermediate species $\left[(b p y){ }_{2} R u^{I I}\left\{L^{\mathrm{sq}, \mathrm{q}}\right\}\right.$ $\left.\mathrm{Ru}^{\mathrm{II}}(\mathrm{bpy})_{2}\right]^{3+}\left(\mathbf{5}^{+}\right)$exhibits weakly rhombic EPR spectrum $\left(g_{1}=2 \cdot 096, g_{2}=2.015, g_{3}=\right.$ 1.972 in $\mathrm{CH}_{2} \mathrm{Cl}_{2}$ at $77 \mathrm{~K}$ ), implying that the unpaired electron in $\mathbf{5}^{+}$is primarily localised onto the ligand centre $\left(\mathrm{L}^{\mathrm{sq}, \mathrm{q}}\right)$ with a small amount of unpaired spin-density on the ruthenium centre ${ }^{10}$. The bridging ligand $\left(\mathrm{L}^{\mathrm{sq}, \mathrm{sq}}\right)$ in $\mathbf{5}$ successively reduces to [ $(\mathrm{bpy})_{2} \mathrm{Ru}{ }^{\mathrm{II}}$ $\left.\left\{\mathrm{L}^{\text {sq,cat }}\right\} \mathrm{Ru}^{\mathrm{II}}(\mathrm{bpy})_{2}\right]^{+}(\mathbf{5})$ and then $\left[(\mathrm{bpy})_{2} \mathrm{Ru}^{\mathrm{II}}\left\{\mathrm{L}^{\text {cat,cat }}\right\} \mathrm{Ru}^{\mathrm{II}}(\mathrm{bpy})_{2}\right]\left(\mathbf{5}^{2-}\right)$ at $-0.98 \mathrm{~V}$ and $-1.38 \mathrm{~V}$ respectively. Moreover, successive irreversible $\mathrm{Ru}(\mathrm{II}) / \mathrm{Ru}(\mathrm{III})$ oxidation processes are observed at 1.49 and $1.70 \mathrm{~V}$ which correspond to the $K_{c}=8 \times 10^{3}$, implying a moderately coupled class II species.

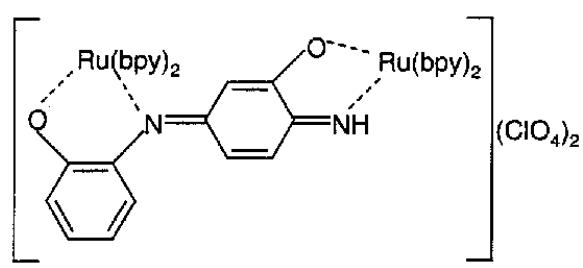

5

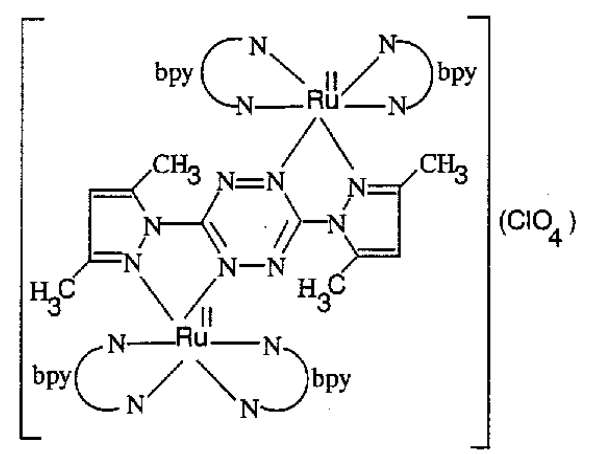

6

The initial sq,sq complex (5) exhibits $\mathrm{Ru}(\mathrm{II}) \rightarrow \mathrm{L}^{\mathrm{sq}, \mathrm{sq}}$ and $\mathrm{Ru}(\mathrm{II}) \rightarrow$ bpy $\mathrm{MLCT}$ transitions at $860 \mathrm{~nm}$ and $525 \mathrm{~nm}$ respectively. However, the $860 \mathrm{~nm}$ band corresponding to the $\mathrm{Ru}(\mathrm{II}) \rightarrow \mathrm{L}^{\mathrm{sq}, \mathrm{sq}}$ transition has been splitted into two closely-spaced components, at 892 and $984 \mathrm{~nm}$ on electrochemical one-electron oxidation to asymmetric bridging centre $(\mathrm{sq}, \mathrm{q})$ in $\mathbf{5}^{+}$. The intra-ligand charge transfer transition between the semiquinone and quinone termini in $\mathbf{5}^{+}$has been observed at $1570 \mathrm{~nm}$ which however, disappears on further oxidation to symmetric q,q species $\left(\mathbf{5}^{2+}\right)$. On one-electron reduction to $\mathbf{5}^{-}$(sq,cat 
species) the lowest energy MLCT transition has been shifted to1306 $\mathrm{nm}$ corresponding to the $\mathrm{Ru}(\mathrm{II}) \rightarrow \mathrm{SOMO}\{\mathrm{L}(\mathrm{cat}, \mathrm{sq})\}$ MLCT transition. Further, on one-electron reduction to cat,cat state $\left(\mathbf{5}^{2-}\right)$, the $1306 \mathrm{~nm}$ transition disappears as the vacancy in the SOMO is filled and consequently $\mathrm{Ru}(\mathrm{II}) \rightarrow$ bpy transition at $539 \mathrm{~nm}$ becomes the lowest energy MLCT transition.

The reaction of potentially binucleating neutral bridging ligand, 3,6-bis(3,5dimethylpyrazol-1-yl)-1,2-dihydro-1,2,4,5-tetrazine, $\mathrm{H}_{2} \mathrm{~L} \quad(\mathbf{V})$ with $\left[\mathrm{Ru}(\mathrm{bpy})_{2}(\mathrm{EtOH})_{2}\right]^{2+}$ produces a diruthenium complex of the type $\left[(\text { bpy })_{2} R u^{\mathrm{II}}(\mathrm{L}) \mathrm{Ru}{ }^{\mathrm{II}}(\mathrm{bpy})_{2}\right]^{4+}, 6^{11}$. Although the preformed $\mathrm{H}_{2} \mathrm{~L}$ is stable enough both in the solid and solution states and requires treatment with strong chemical oxidants to be converted to $\mathrm{L}^{12}$, during the course of the metallation process $\mathrm{H}_{2} \mathrm{~L}$ undergoes facile oxidative dehydrogenation to give one aromatic tetrazine unit $(\mathrm{L})$ in $\mathbf{6}$. The crystal structures of the free ligand $\left(\mathrm{H}_{2} \mathrm{~L}\right)$ and the complex 6 have been determined. The complex 6 exhibits two reversible $\mathrm{Ru}(\mathrm{II}) / \mathrm{Ru}(\mathrm{III})$ couples at 1.25 and $1.70 \mathrm{~V}$ vs SCE, corresponding to the $K_{c}=4 \times 10^{7}$. The tetrazine based two oneelectron reversible reductions are observed at -0.13 and $-0.99 \mathrm{~V}$ vs SCE. The electrochemically generated one-electron reduced species shows an EPR signal at $g=2.0085$ with a peak-peak separation of $45 \mathrm{G}$ with some poorly resolved fine structures due to hyperfine coupling to the $\mathrm{N}$-atoms, indicative of a largely tz-centred radical ${ }^{13}$. The $\mathrm{Ru}(\mathrm{II}) \rightarrow\left(\pi^{*}\right) \mathrm{L}$ and $\mathrm{Ru}(\mathrm{II}) \rightarrow\left(\pi^{*}\right)$ bpy based MLCT transitions are observed at $757 \mathrm{~nm}$ and $400 \mathrm{~nm}$ respectively. For the mixed-valence $\mathrm{Ru}^{\mathrm{II}} \mathrm{Ru}^{\mathrm{III}}$ complex $\left(6^{+}\right)$the $\mathrm{Ru}(\mathrm{II}) \rightarrow\left(\pi^{*}\right) \mathrm{L}$ transition is blue shifted to $633 \mathrm{~nm}$ and one sharp and intense $\pi-\pi^{*}$ type transition has been observed at $1534 \mathrm{~nm}$ with a band width at half height, $\Delta v_{1 / 2}=650 \mathrm{~cm}^{-1}$ and the electronic coupling parameter, $V_{\mathrm{ab}}=3260 \mathrm{~cm}^{-1}$, characteristics of a strongly coupled class III species ${ }^{14}$. On further oxidation to $6^{2+}\left(\mathrm{Ru}^{\mathrm{III}} \mathrm{Ru}^{\mathrm{III}}\right.$ configuration) the remaining ruthenium(II) based MLCT transitions and the $\pi-\pi^{*}$ transition are replaced by ligand $\rightarrow \mathrm{Ru}(\mathrm{III})$ LMCT transition at $522 \mathrm{~nm}$.

The asymmetric bridging ligands 2-thiouracil $\left(\mathrm{H}_{2} \mathrm{~L}^{1}\right)$ and 6-methyl-2-thiouracil $\left(\mathrm{H}_{2} \mathrm{~L}^{2}\right)$, VI yield dinuclear complexes of the type $\left[\left\{(\text { bpy })_{2} \mathrm{Ru}\right\}_{2}\left(\mu \mathrm{L}^{2-}\right)\right]^{2+}$, where $\mathrm{L}=\mathrm{L}^{1}$ (complex 7) or $\mathrm{L}^{2}$ (complex 8) in which the bridging functions act as a dinegative unit and bind with the two $\left[\mathrm{Ru}(\mathrm{bpy})_{2}\right]^{2+}$ units through the terminal $\mathrm{N}, \mathrm{S}$ and $\mathrm{N}, \mathrm{O}$ donor sites ${ }^{15}$. The crystal structure of $\mathbf{8}$ has been determined, which suggests that one negative charge is associated with each binding site i.e. L behaves like a combination of pyridonate and thiopyridonate ligands ${ }^{16}$. The stepwise one-electron $\mathrm{Ru}(\mathrm{II}) / \mathrm{Ru}(\mathrm{III})$ couples for 7 appear at half-wave potentials $0 \cdot 17$ and $0 \cdot 87 \mathrm{~V}$ vs SCE. The large separation of $700 \mathrm{mV}$ between the successive $\mathrm{Ru}(\mathrm{II}) / \mathrm{Ru}$ (III) couples arises presumably due to the combination of the inherent difference in redox potentials associated with the chemically different sites at the bridging termini and an electronic interaction between the metal centres mediated by the

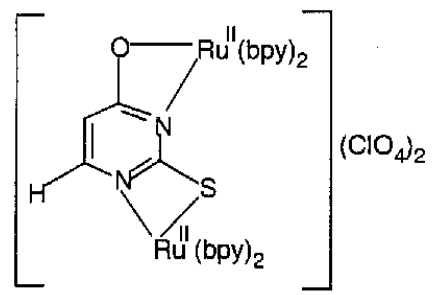

7

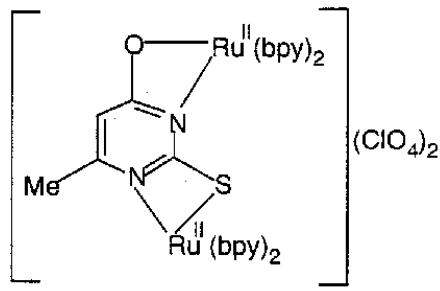

8 
$\pi$-orbitals of the bridging ligand. The successive $\mathrm{Ru}(\mathrm{II}) / \mathrm{Ru}(\mathrm{III})$ couples for $\mathbf{8}$ appear at 0.41 and $0.72 \mathrm{~V}$ with a separation of $310 \mathrm{mV}$. Both the complexes display a third oxidation process in the range $1.54-1.6 \mathrm{~V}$ vs SCE, which is believed to be a process involving the thiolato unit of the bridging ligand ${ }^{17}$. The large decrease in separation of potentials of the successive $\mathrm{Ru}(\mathrm{II}) / \mathrm{Ru}(\mathrm{III})$ couples while moving from $7(700 \mathrm{mV})$ to $\mathbf{8}$ $(310 \mathrm{mV})$ possibly develops due to the steric hindrance associated with the presence of the methyl group on the bridging ligand $\left(\mathrm{L}^{2}\right)$ of $\mathbf{8}$. This has been clearly reflected in the crystal structure of $\mathbf{8}$ where the adjacent $\mathrm{Ru}-\mathrm{N}$ bond at the $\mathrm{RuN}_{5} \mathrm{~S}$ site is elongated. The mixed valence $\mathrm{Ru}^{\mathrm{II}} \mathrm{Ru}{ }^{\mathrm{III}}$ species $[7]^{+}$and $[8]^{+}$display a broad intervalence charge-transfer transition (IVCT) at $1160 \mathrm{~nm}$ and $1140 \mathrm{~nm}$ respectively. The widths at half height for these IVCT transitions are 3060 and $2400 \mathrm{~cm}^{-1}$ and electronic coupling constant, $V_{\mathrm{ab}}$ of $950 \mathrm{~cm}^{-1}$ for $[7]^{+}$and $900 \mathrm{~cm}^{-1}$ for $[8]^{+}$respectively, which are characteristics of moderately coupled class II complexes ${ }^{18}$. The fractionally weaker coupling in $[8]^{+}$may be a reflection of elongated $\mathrm{Ru}-\mathrm{N}$ bond to the bridging ligand which also resulted in a reduced separation between the redox potentials.

\section{Conclusions}

The present discussion primarily illustrates the following three important aspects: (i) the role of $\mathrm{Ru}(\mathrm{bpy})_{2}$ core in facilitating the selective organic transformations of the coordinated bridging functions in the complexes $3,4,5$ and 6 , (ii) the role of electronic nature of the bridging units in mediating the electronic coupling between the metal centres across the bridges in the mixed valent dinuclear species $\mathbf{1}^{+}, \mathbf{2}^{+}, \mathbf{5}^{+}, \mathbf{6}^{+}$and $7^{+}$, and (iii) the steric effect of the methyl substituent associated with the bridging function in $\mathbf{8}$ with specific reference to the intermatallic electronic coupling.

\section{Acknowledgements}

Financial support received from the Department of Science and Technology, New Delhi and Council of Scientific and Industrial Research, New Delhi is gratefully acknowledged. The authors also wish to thank Professor M D Ward, Bristol University, UK for spectroelectrochemical and crystallographic studies.

\section{References}

1. (a) Balzani V, Zuris A, Venturi M, Campagna S and Serroni S 1996 Chem. Rev. 96 759; (b) Scandola F, Indelli M T, Chiorboli C and Bignozzi C A 1990 Top. Curr. Chem. 158 73; (c) Dodsworth E S, Vleck A A and Lever A B P 1994 Inorg. Chem. 33 1045; (d) Amouyal E 1995 Sol. Energy Mater. Sol. Cells 38 249; (e) Kay A and Grätzel M 1996 Sol. Energy Mater. Sol. Cells 44 99; (f) Argazzi R, Bignozzi C A, Hasselman G M and Meyer G J 1998 Inorg. Chem. 374533

2. (a) Balzani V and Scandola F 1991 Supramolecular photochemistry (New York: Ellis Horwood); (b) Hatzidimitriou A, Gourdon A, Devillers J, Launay J-P, Mena E and Amouyal E 1996 Inorg. Chem. 352212

3. (a) Erkkila K E, Odom D T and Barton J K 1999 Chem. Rev. 29 2777; (b) Barton J K, Danishefksy A T and Goldberg J M 1984 J. Am. Chem. Soc. 106 2172; (c) Kelly J, Tossi A, McConnel D and Ohuigin C 1985 Nucleic Acids Res. 13 6017; (d) Ambroise A and Maiya B G 2000 Inorg. Chem. 394264

4. (a) Jordan K D and Paddon-Row M N 1992 Chem. Rev. 92 395; (b) Todd M D, Nitzan A and Ratner M A 1993 J. Phys. Chem. 97 29; (c) Isied S S, Vassilian A, Wishart J F, Creutz C, Schwartz H A and Sutin N 1998 J. Am. Chem. Soc. 110 635; (d) Beratan D N and Onuchic J N 
1991 Science 252 1285; (e) Kaim W, Klein A and Glöckle M 2000 Acc. Chem. Res. 33 755; (f) Crutchley R J 1994 Adv. Inorg. Chem. 41 273; (g) Laye R H, Couchman S M and Ward M D 2001 Inorg. Chem. 404089

5. Chakraborty S, Munshi P and Lahiri G K 1999 Polyhedron 181437

6. Chakraborty $S$ and Lahiri G K, unpublished results

7. Robin M B and Day P 1967 Adv. Inorg. Chem. Radiochem. 10247

8. Chakraborty S, Walawalkar M G and Lahiri G K 2000 J. Chem. Soc., Dalton Trans. 2875

9. Chakraborty S, Laye R H, Paul R L, Gonnade R G, Puranik V G, Ward M D and Lahiri G K 2002 J. Chem. Soc., Dalton Trans. 1172

10. Bag N, Pramanik A, Lahiri G K and Chakravorty A 1992 Inorg. Chem. 3140

11. Sarkar B, Laye R H, Mondal B, Chakraborty S, Paul R L, Jeffery J C, Puranik V G, Ward M D and Lahiri G K 2002 J. Chem. Soc., Dalton Trans. 2097

12. Coburn M D, Buntain G A, Harris B W, Hiskey M A, Lee K Y and Ott D G 1991 J. Heterocycl. Chem. 282049

13. Glockle M, Kaim W, Klein A, Roduner E, Hubmer G, Zalis S, Slageren J, Renz F and Gutlich P 2001 Inorg. Chem. 402256

14. Chellamma S and Lieberman M 2001 Inorg. Chem. 403177

15. Chakraborty S, Laye R H, Munshi P, Paul R L, Ward M D and Lahiri G K 2002 J.Chem. Soc., Dalton Trans. 2348

16. Rawson J M and Winpenny R E 1995 Coord. Chem. Rev. 139313.

17. (a) Santra B K and Lahiri G K 1997 J. Chem. Soc., Dalton Trans. 129; (b) Santra B K and Lahiri G K 1997 J. Chem. Soc., Dalton Trans. 1883

18. (a) Ward M D 1995 Chem. Soc. Rev. 24 121; (b) Baitalik S, Florke U and Nag K 1999 J. Chem. Soc., Dalton Trans. 719 